められ、両者は別当谷、甚之助谷附近で交わる。

地宅り対策の新方向

\title{
柴 崎達雄（農林省農地的）
}

災害地質研究連絡紙 No.6 1957年7月

地云りに関する研究括よび䛻査が最近著しくす」められ、地云りの主因が だんだんはつきりしてきた。

とくに、地之りを地質構造一破砕带一と関連させることにより、地之り地 にともな5諸現象が比较的統一されて理解することができる。

このように地方りが現世に抢ける地殼峦動をしめす一現象であるというこ とが判明するにつれて、今まで長年とられて来た地文り対策工事一地方りは 完全にとめられるといら考えから出発した対策、たと党ば砂防堰堤を設置する とか、地上水排水工などーの矛盾がはつきりした形であらわれてきている。

それでは、地方り対策は全然皆無で野ばなしでよいかという舫になるが、 はたしてそうであろうか。

最近の調査によつて、弫とんど常識化してきたこと〉して、地六り地の土 地の生痤性が、非地方り地と比較して高いという事奏があげられる。この事 契は各地方によつて多少の相違こそあ地方り地に共通なことである。

要するに地之りに関しては、災害性という性質と、それとは相反する非災 害性の性質という雨面をるつているということになる。

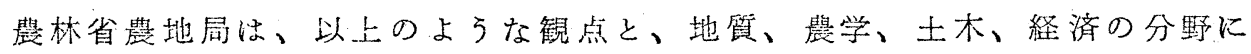
わたつて、昭和 31 年度から 3 年計画で、代表的な地文り地带についての綜

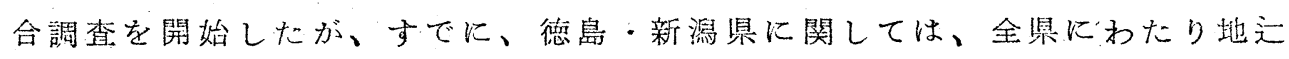
り台帳を作成し、帮態調査が行われた。

この調查の特徴は、地文りの土地利用という観点を主眼とし、あわせて、 地之り地と、地質学的現象の関速性を层い範团と見地からをとめるというこ とにある。

今まで、一応仮説とされていたものを、はつきりした慗実として、地亡り 対策の新方向をはつきりきめる基準資料として、この調査をまとめたいと考 えている。 
このような調查に従事する地質研究者として、いろいろの分野にまたがる 現象を地質学という見地からまとめていくことが、いかに重大でまた困難な 仕事であると通感するものである。

\section{万葉に歌われた地穴り}

\section{小出博 (東京農業大学)}

応用地質研究連絡紙。10.9 1958 年3月

去年の夏、信州の娽撘山に出かけた。こ〉は善论寺平の南側の山に"田每 の月"をうつして一面にひらけた棚田地带である。その棚田の調査に出かけ たわけである。

一体棚田地带の開発は非常に古く、数百年あるいは干年以上もまえから、 こっで稲作压業が行われたらしいことが、ちか頃だんだんわかつてきた。姨 管山の稝田も" “平家村”と伝わる上水内郡や夷級郡の、地文り地带の傾斜畑 とともに数百年の古い開発史をもつているらしい。「信州㛝唅山縁記」によ ると、すでに千年以上も前から、月の名所として紀貫えの歌になど見えるが 何といつても"空に一つあまりて月の田毎かな”と誈んだ范蕉の一句は棚田

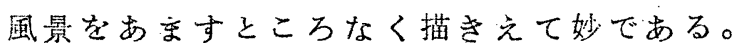

ところでこのような地文り地带の棚田について、米の収量を費林統計調查 事務所で調べて兒ると、姨唅山一带の平均反収は三石三斗三升五合るある。 盖光寺平の反収が三石四升五合で、長野県の平均が二石七斗六升といらから 棚田の生産力がいかに高いか心゙よくわかるであろう。棚田や傾斜畑で米妾そ の他の農産物の収量が高いことは、最近各地で注意されてきたが、地方り地 带の榴作の中には、原始水稲作はこうでもあつたかと思わせる面白い例むあ る。

新潟県の東頸城郡では、地方り地の沼沢でよしやあしを技きとり、胸まで 水につかりながら手足で沼をかさまわし、它のあとにるみを直播きする。そ して䑲肥料のまっ二石五斗以上、或いは三石もの区収をあげているところが ある。费具も使わず、まるで原始的な米造りで、しかも高い収獲を上げてい るわけである。

こっ数年、地艺り地帶の棚田や傾斜畑の発達を、このような角度から眺め 